\title{
ЖЕСТИКУЛЯЦІ ВЧИТЕЛЯ У СТРУКТУРІ ЗОВНІШНЬОЇ ПЕДАГОГІЧНОЇ ТЕХНІКИ
}

\author{
У статті розглядається значення жестикуляції вчителя у структурі зовнішньої педагогічної техніки та аналізуються \\ особливості ї̈ використання в професійно-педагогічній діяльності. \\ Ключові слова: жестикулячія, зовнішня педагогічна техніка, невербальна комунікація. \\ В статье рассматривается значение жестикуляиии учителя в структуре внешней педагогической техники $и$ \\ анализируются особенности ее использования в профессионально-педагогической деятельности. \\ Ключевые слова: жестикуляиия, внешняя педагогическая техника, невербальная коммуникачия. \\ In the article the author considers the importance of teacher's gesticulation in the outward structure of the pedagogical \\ technique and analyzes the characteristics of its use in professional and pedagogical activities. \\ Key words: gesticulation, outward pedagogical technique, non-verbal communication.
}

У процесі взаємодії в системі «вчитель - учень» невербальне спілкування посідає важливе місце. Тому вчитель повинен володіти не тільки високою мовленнєвою культурою, але й культурою емоційно-експресивної невербальної поведінки, або культурою використання так званих виразних рухів, оскільки відомо, що різні види невербального спілкування містять у собі часом набагато більше інформації, ніж слова. У зв'язку із цим проблема значущості та важливості невербального компонента в структурі педагогічної діяльності заслуговує на особливу увагу й вимагає ретельного дослідження.

Проблема інтерпретації невербальних аспектів міжособистісного спілкування має багатовікову історію, однак детально стала розроблятися лише в останні десятиліття. Дослідженню засобів невербальної комунікації присвячені роботи В. Біркенбіла, І. Горєлова, Г. Кириленка, М. Крічлі, В. Лабунської, Ч. Морріса, О. Леонтьєва, А. Піза, Дж. Фаста, Р. Хорста й ін. Є. Петрова, Л. Туміна, Н. Федорова у своїх наукових розвідках здійснили аналіз значення невербальної комунікації в педагогічній діяльності. Особливості жестикуляції активно розглядалися в працях М. Арджайла, А. Брассера, В. Лабунської, А. Піза, О. Савостьянова, А. Штангеля, Г. Щокіна. Але незважаючи на значну кількість наукових досліджень, проблема жестикуляції педагога залишається недостатньо вивченою.

Mema cmammi - визначити значення жестикуляції педагога у структурі зовнішньої педагогічної техніки та проаналізувати особливості ії̈ використання в професійній діяльності.

Зовнішня педагогічна техніка - це виявлення внутрішнього стану вчителя через його анатомофізіологічний апарат - рухи м'язів обличчя, рук і тіла та їх пластики, мовлення в їх гармонійній єдності. У процесі взаємодії в системі «вчитель - клас» невербальне спілкування здійснюється через такі канали: міміка, жест, дистанція, візуальний контакт, інтонація, дотик. При цьому дані канали $є$ найважливішими засобами педагогічного впливу.

Зовнішня педагогічна техніка вчителя розглядається як один із засобів вияву педагогом своєї особистості, професіоналізму, що значно розширює педагогічні можливості впливу на учнів.

Учителю необхідно знати й ураховувати свої індивідуальні особливості: стримувати вияви агресії, гарячковості, контролювати жести невпевненості чи непоступливості тощо. На особливу увагу заслуговує така група знаків мови рухів тіла, як жести. Учителю треба пам'ятати, що в кожному його жесті виявляється майстерність, професіоналізм, а також ставлення до певної ситуації, особистості учня.

Жести (від. лат. gesta - діяння) - виражальні рухи голови, тіла, рук - є важливим засобом посилення виразності читання, мовлення. У психології склалася традиція вивчення жестів як паралінгвістичних засобів. Водночас жести в процесі спілкування не лише супроводжують мову, на їх основі можна скласти враження про ставлення людини до якоїсь події, особи, предмета. Жест може також сказати про бажання людини, його стан. Особливості жестикуляції людини можуть послужити підгрунтям для висновку про певну якість людини, що сприймається. Тому жести можна 3 упевненістю віднести до виразних рухів і розглядати їх не лише як вияв спонтанної активності людини.

Людина, формуючись як особистість у конкретному соціальному середовищі, засвоює характерні для цього середовища способи жестикуляції, правила їх застосування і прочитання. Звичайно, людина може жестикулювати як довільно, так і мимоволі. Жести можуть бути типовими для цієї людини і зовсім не характерними для неї, виражати ії випадкові стани. На думку дослідників, жест несе інформацію не стільки про якість психічного стану, скільки про інтенсивність його переживання.

Н. Смирнова на основі порівняльного аналізу міміки, жестів, поз пропонує таку класифікацію:

Перша група жестів - комунікативні жести, міміка, рухи тіла, тобто виразні рухи, що заміщають елементи мови. Це - вітання і прощання; жести загрози, привертання уваги, що кличуть, запрошують, 
забороняють; образливі жести і рухи тіла, що дратують, такі, що зустрічаються у спілкуванні дітей; ствердні, заперечні, питальні, жести вдячності, примирення; а також жести, що зустрічаються в різних інших ситуаціях міжособистісного спілкування. Усі названі жести зрозумілі без мовного контексту і мають власне значення в спілкуванні.

Друга група жестів - описово-образотворчі, підкреслю-вальні. Вони, як правило, супроводжують мову і поза мовним контекстом утрачають сенс.

III група - модальні жести. Іх можна віднести до виразних дій, оскільки вони виражають оцінку, ставлення до предметів, людей, явищ довкілля. До модальних жестів відносять: жести схвалення, незадоволення, іроніі, недовіри; жести, які передають невпевненість, незнання, страждання, роздум, зосередженість; розгубленість, замішання, пригнічення, розчарування, відразу, радість, захват, здивування [5].

Жестикуляція вчителя відрізняється від виражальних рухів людини, характерних для повсякденної поведінки людини, насамперед комунікативною виправданістю. Для того, щоб уміти контролювати свої жести, необхідно знати їх класифікацію. За приналежністю жести поділяються на фізіологічні, не пов'язані безпосередньо 3 процесом читання, мовлення, й комунікативно значущі. Усі жести класифікують за: структурою (прості, складні, складені); характером створення (вказівні, зображальні, символічні, ритмічні, емоційні або психологічні); співвідносністю з вербальними засобами спілкування [2, c. 131-132].

Розглянемо класифікацію жестів, у якій виокремлюють три групи жестів за критерієм співвіднесеності з мовними засобами: 1. Жести, що можуть доповнювати чи повністю заміщати мовленнєві форми: вони зрозумілі без слів, поза мовленнєвим контекстом. До цієї групи відносять загальновідомі жести-символи, про які слід пам’ятати, що вони мають національну специфіку, і той самий жест-символ у різних народів має різне смислове навантаження. Найбільш універсальними $є$ жести повсякденного міжособистісного спілкування: етикетні жести привітання, прощання, привертання уваги, заборони чи дозволу, погодження чи заперечення. 2. Жести, які органічно вплітаються в контекст мовлення. Їх застосовують, використовуючи наочність невербальних засобів інформації. Так, іноді жест, який указує на розмір чи форму предмета, з успіхом замінює більш поширене, однак менш виразне вербальне пояснення. 3. Жести, які вживаються паралельно зі словами i можуть дублювати чи доповнювати значення мовних засобів, наприклад, жест, що супроводжується фразою: «Зверніть увагу на портрет письменника», зазвичай доповнюється вказівним жестом, який привертає увагу учнів та підказує їм напрямок погляду.

Учитель постійно перебуває в центрі уваги учнів, тому жести педагогу доводиться контролювати. Настрій педагога одразу передається класу, і робота на уроці часто залежить від першої хвилини невербального контакту (форми привітання, інтонування першої фрази тощо). Контролюючи жести, учитель намагається приховати фізичне нездужання, втому чи просто зіпсований настрій, які можуть вплинути на темп та результативність роботи на уроці. Важливо не тільки вміти контролювати свої жести «самовираження», а й розкодовувати жести учнів, щоб своєчасно помітити перші ознаки втрати уваги, переключити іiі, знайти засоби викликати інтерес, зняти психічну напругу, зробити паузу для відпочинку, якщо діти перевтомилися. Педагог стежить за реакцією всього класу й кожного учня окремо. Основними ознаками втоми виявляються насамперед розслаблена поза, важка опора на парту, на руку, опущена голова; запитливий погляд, мимовільні рухи рук (учень дивиться на вчителя, а в руках крутить якийсь предмет, наприклад, олівець) свідчать про нерозуміння матеріалу; школяр намагається стати «непомітним» (опускає очі, голову втягує в опущені плечі) - неготовність до відповіді, дискомфорт від спілкування з учителем.

Рухи рук, які змальовують предмет, викликають додаткові зорові асоціації, допомагають створити образ цього предмета. Жести-інформатори нерідко використовуються вчителями під час лекції 3 метою підкреслення структурних компонентів цієї форми спілкування. Серед таких жест перерахування (загинання пальців руки), який визначає кількість аргументів чи питань, що розглядаються; жести-наголошення на певному аспекті питання (стиснутий кулак), пропозиція зважати на якийсь план або оцінити певну дію (долоня, обернута догори), жести на означення 3'єднання (зустрічний рух рук, з'єднання долонь, стискання пальців в кулак) чи роз'єднання (розведення рук), наближення й віддалення (рухи рук до себе й від себе), підкреслювання (різкий горизонтальний рух руки), незгоди, презирства, відмови (долоня, обернута донизу); вказівні жести, які підкреслюють окремі складові запису, схеми, таблиці, репродукції, ілюстрації в книзі чи на дошці.

Інформаційно-ритмічні жести («диригування», постукування рукою чи ногою в такт мовленню) допомагають відчути членування тексту на мовні такти, його мелодику, визначити віршовий розмір.

Розрізняють три рівні, на яких можна жестикулювати: нижній рівень (від попереку вниз), середній (між попереком і плечима); високий (від плечей угору).

Жести на нижньому рівні виражають думки й почуття, найчастіше пов’язані з такими негативними почуттями, як злість, ненависть, незгода, опір. На верхньому рівні жестикулюють, коли говорять про величні ідеали і коли звертаються до високих почуттів. Однак більшу частину педагогічної взаємодії супроводжує жестикуляція в межах середнього рівня. 
Жести самого вчителя повинні бути естетичними (адже вони є елементом загальної культури людини), невимушеними, стриманими, доцільними і конгруентними, тобто мають відповідати словесним сигналам. Якщо жести не є конгруентними, то слухачі більше довіряють жестам, аніж словам. При цьому варто враховувати, що жести, як і інші рухи корпуса, найчастіше випереджають хід висловлюваної думки, а не йдуть за нею [3].

Жести вчителя не повинні мати фамільярного або вульгарного відтінку, недопустимим $є$ використання жестів жаргонного характеру. Із перших хвилин спілкування вони мають створювати певний настрій: плавні, рівномірні жести сприяють встановленню спокійної робочої обстановки. Найкращий жест той, який настільки органічний, що є непомітним.

Таким чином, володіння засобами невербальної комунікації, особливо жестикуляцією, сприяє досягненню зовнішньої виразності педагога, який повинен навчитися диференціювати й адекватно інтерпретувати невербальну поведінку учнів, розвивати вміння «читати за обличчям», розуміти мову тіла, час, простір у спілкуванні; прагнути розвивати, розширювати діапазон засобів спілкування шляхом тренувальних вправ і самоконтролю зовнішньої техніки; домагатися того, щоб використання зовнішньої педагогічної техніки було органічно пов'язане з внутрішнім переживанням як логічне продовження педагогічного завдання, думок та почуттів.

\section{Література}

1. Лабунская В. А. Введение в психологию невербального поведения / В. А. Лабунская. - Ростов-на-Дону : РГУ, 1994. - 30 с. 2. Лабунская В. А. Невербальное поведение (социально-перцептивный подход) ; В. А. Лабунская. - Ростов-на-Дону : Феникс, 1988. - 246 с. 3. Морозов В. П. Искусство и наука общения: невербальная коммуникация / В. П. Морозов. - М. : Изд-во ИП РАН, 1998. - 164 с. 4. Педагогічна майстерність / за ред. І. А. Зязюна. - К. : Вища школа, 1997. - С. 57-66. 5. Петрова Е. А. Жесты в педагогическом процессе / Е. А. Петрова. - М. : Мос. гор. пед. об-во, 1998. - 222 с. 6. Пиз А. Язык жестов: как читать мысли других людей по их жестам / Аллан Пиз. - М. : Ай-Кью, 1995. - 257 с. 